\title{
Kemampuan Pemecahan Masalah Melalui Pembelajaran Interactive Demonstration Siswa Kelas X SMA pada Materi Kalor
}

\author{
Rismatul Azizah, Lia Yuliati, Eny Latifah \\ Pascasarjana Program Studi Pendidikan Fisika. \\ Universitas Negeri Malang. \\ Malang, Indonesia \\ Email : rismatulazizah89@gmail.com.
}

\begin{abstract}
The application of teacher centered learning in classroom is causing the underdevelopment of students problem solving ability and students activity in learning. Interactive demonstration is an active learning model developed by Wenning. Through interactive demonstrations, students can use the basic intellectual process skills that includes predicting, explaining, estimating, acquiring and processing data, formulating and revising scientific explanations using logic and evidence, and recognizing and analyzing alterative xplanations and models. The purpose of this research is to determine the effect of interactive learning demonstration toward students' problem solving ability. This research was mixed method research with embedded design. The sample is selected by purposive sampling method, that was the grade X MIA 1 students of SMAN 1 Bangil. The results of this study indicate that there is the effect of interactive demonstration learning and that learning can enhance students' problem-solving abilities.
\end{abstract}

Keywords : interactive demonstration, problem solving ability.

\section{PENDAHULUAN}

Fisika merupakan salah satu bagian dalam Ilmu Pengetahuan Alam yang berasal dari fenomena alam. Dalam belajar fisika, keaktifan siswa sangat diperlukan. Keaktifan dalam belajar fisika terletak pada dua segi, yaitu aktif dalam bertindak (hands activity) dan aktif berpikir (minds activity) ${ }^{[1]}$. Mims menyebutkan bahwa siswa akan aktif jika siswa dapat menghubungkan pengetahuan baru dengan pemahaman awal mereka ${ }^{[2]}$. Namun menghubungkan antara keduanya dalam pembelajaran fisika tidaklah mudah.

Pembelajaran fisika memiliki tujuan diantaranya mengembangkan pengetahuan, pemahaman, dan kemampuan analisis siswa terhadap lingkungan dan sekitarnya. Pembelajaran fisika pada siswa diharapkan tidak hanya untuk menguasai konsep tetapi juga menerapkan konsep yang telah mereka pahami dalam penyelesaian masalah fisika. Namun, pembelajaran dalam kelas cenderung menekankan pada penguasaan konsep dan mengesampingkan kemampuan pemecahan masalah fisika siswa ${ }^{[3]}$.

Pada pembelajaran fisika, kemampuan menyelesaikan masalah siswa masih tergolong rendah. Dalam mengerjakan soal-soal fisika yang diberikan guru, siswa lebih sering menggunakan persamaan matematis tanpa melakukan analitis, menebak rumus yang digunakan dan menghafal contoh soal yang telah dikerjakan untuk mengerjakan soal-soal lain. Menurut Wlash\&Bowe dan Brad, siswa masih sering menggunakan pendekatan plug and chug dan memory based dalam menyelesaikan soal-soal fisika ${ }^{[4,5]}$. Ada beberapa faktor yang mempengaruhi lemahnya kemampuan pemecahan masalah siswa. Menurut Ogunleye, siswa tidak dapat menyelesaikan masalah meliputi tidak cukup praktikum di laboratorium, bingung menulis konversi satuan, kurangnya buku fisika yang digunakan sebagai referensi ${ }^{[6]}$. Menurut Ikhwanuddin, kurangnya kemampuan pemecahan masalah meliputi pemahaman yang lemah tentang prinsip dan aturan fisika, kekurangan dalam memahami soal, dan tidak cukup motivasi dari siswa ${ }^{[7]}$.

Proses pembelajaran fisika akan bermakna dan menyenangkan apabila dilakukan dengan cara metode ilmiah disertai penalaran kognitif terhadap data yang diperoleh maupun gejala alam yang teramati ${ }^{[8]}$. Pembelajaran aktif dapat membuat proses belajar lebih menyenagkan untuk guru dan siswa. Salah satu model pembelajaran aktif yang dipandang dapat mengembangkan kemampuan berpikir dan kemampuan pemecahan masalah siswa adalah interactive demonstration. Interactive demonstration merupakan model pembelajaran aktif yang dikembangkan oleh Wenning dan merupakan tahapan kedua pada level of Inquiry. Interactive demonstration umumnya dimulai dengan guru melakukan demonstrasi, kemudian guru mengajukan pertanyaan menyelidik tentang apa yang akan terjadi (siswa melakukan prediksi), bagaimana atau mengapa sesuatu yang mungkin terjadi (siswa memberi penjelasan).

Menurut Wenning pembelajaran interactive demonstration melibatkan siswa dalam memprediksi dan membuat penjelasan suatu konsep fisika yang memungkinkan guru untuk memperoleh, mengidentifikasi, menghadapi, dan menyelesaikan 
konsep alternatif (pengalaman pengetahuan sebelumnya ${ }^{[9]}$. Melalui demonstrasi interaktif, siswa menggunakan keterampilan proses intelektual dasar yang meliputi: 1) memprediksi, 2) menjelaskan, 3) memperkirakan, 4) memperoleh dan pengolahan data, 5) merumuskan dan merevisi penjelasan ilmiah menggunakan logika dan bukti, dan 6) mengenali dan menganalisis penjelasan pergantian dan model ${ }^{[9]}$.

\section{TINJAUAN PUSTAKA}

\section{A. Model Pembelajaran Demonstration}

Interactive

Interactive demonstration merupakan model pembelajaran aktif yang dikembangkan oleh Wenning dan merupakan tahapan kedua pada level of inquiry. Spektrum inkuiri (level of inquiry) adalah pendekatan hirarki ilmu mengajar dengan cara yang mungkin untuk meningkatkan pemahaman konseptual siswa serta mengembangkan pemahaman penyelidikan ilmiah siswa.

Menurut Violeta dan Loreta kegiatan interactive demonstration meliputi demonstrasi yang dilakukan oleh guru mengenai percobaan yang berlangsung interaktif, kemudian siswa memprediksi dan menjelaskan bagaimana sesuatu dapat terjadi ${ }^{[10]}$. Interactive demonstration umumnya dimulai dengan guru melakukan demonstrasi, kemudian guru mengajukan pertanyaan menyelidik tentang apa yang akan terjadi (siswa melakukan prediksi) dan menanyakan bagaimana atau mengapa sesuatu tersebut mungkin terjadi (siswa memberi penjelasan $)^{[11]}$. Pada interactive demonstration, pada awalnya guru melakukan demonstrasi untuk mengembangkan dan mengajukan pertanyaan menyelidik dari siswa, memunculkan tanggapan untuk mengidentifikasi konsepsi alternatif dari siswa, menempatkan siswa dalam kasus disonansi kognitif sehingga mereka mungkin menghadapi konsepsi alternatif yang dapat diidentifikasi. Selanjutnya, guru meminta penjelasan lebih lanjut kepada siswa untuk menyelesaikan konsepsi alternatif, meminta siswa untuk berkomitmen pada prediksinya dan membandingkan prediksi dengan hasil eksperimen yang akan dilakukan, kemudian guru membantu siswa mencapai kesimpulan yang tepat dari buktibukti pada eksperimen. Guru sadar dengan memunculkan prasangka pada siswa dan kemudian siswa diminta menghadapi dan menyelesaikan setiap yang diidentifikasi, disini guru mulai menggeser locus of control dari guru ke siswa, dengan demikian secara implisit guru mengajarkan proses inkuiri pada siswa.

Wenning menjelaskan bahwa terdapat lima tahapan siklus belajar pada level of inquiry yang juga merupakan tahapan siklus belajar pada interactive demonstration, meliputi pengamatan (observation), manipulasi (manipulation), generalisasi (generalization), verifikasi (verification), dan aplikasi (application) $)^{[12]}$. Dari kelima tahapan siklus belajar tersebut, interactive demonstration lebih menekankan pada tahapan kedua yaitu manipulasi (manipulation). Siklus Belajar 5-tahap ini menempatkan penekanan yang konsisten dan kuat pada tindakan siswa bukan pada tindakan guru. Selama proses 5-tahap ini, siswa terus mengkomunikasikan ide-ide, pendekatan, proses, data, dan hasil termasuk kesulitan dan hambatannya. Rincian dari kelima tahapan siklus belajar level of inquiry adalah sebagai berikut:

\section{Tabel 1. The 5-Stage Levels of Inquiry Learning Cycle}

\begin{tabular}{cl} 
Tahapan & \multicolumn{1}{c}{ Keterangan } \\
\hline $\begin{array}{c}\text { Pengamatan } \\
\text { (observation) }\end{array}$ & $\begin{array}{l}\text { Siswa melakukan observasi yang } \\
\text { dilakukan oleh guru. Guru isa } \\
\text { menunjukkan fenomena, gambar, } \\
\text { atau video. }\end{array}$ \\
\hline & $\begin{array}{l}\text { Guru: Guru melakukan manipulasi } \\
\text { terhadap sebuah ilustrasi. Siswa } \\
\text { melakukan prediksi apa yang akan } \\
\text { terjadi pada manipulasi yang } \\
\text { dilakukan oleh guru. }\end{array}$ \\
$\begin{array}{c}\text { Manipulasi } \\
\text { (manipulation) }\end{array}$ & $\begin{array}{l}\text { Siswa: Siswa melakukan } \\
\text { manipulasi dengan mengubah } \\
\text { variabel bebas, kemudian melihat } \\
\text { efeknya pada variabel terikat. }\end{array}$ \\
\hline Generalisasi & $\begin{array}{l}\text { Siswa membuat generalisasi } \\
\text { terhadap manipulasi yang telah } \\
\text { mereka lakukan. }\end{array}$ \\
\hline (generalization) & $\begin{array}{l}\text { Siswa melakukan diskusi kelas } \\
\text { untuk melihat bagaimana hasil } \\
\text { kerja kelompok lain dan saling } \\
\text { bertukar pendapat. }\end{array}$ \\
\hline Verifikasi & $\begin{array}{l}\text { Siswa menerapkannya dalam } \\
\text { kasus lain yang sama namun beda } \\
\text { konteks. }\end{array}$ \\
\hline (verification) & \\
\hline application) &
\end{tabular}

\section{B. Kemampuan Pemecahan Masalah}

Kemampuan pemecahan masalah adalah kemampuan seseorang untuk menemukan solusi melalui suatu proses yang melibatkan pemerolehan dan pengorganisasian informasi. Kemampuan pemecahan masalah memerlukan suatu ketrapilan dan kemampuan khusus yang dimiliki masing-masing siswa, yang mugkin akan berbeda antar siswa dalam menyelesaikan suatu masalah. Kemampuan pemecahan masalah mengacu pada upaya yang diperlukan siswa dalam menentukan solusi atas masalah yang dihadapi ${ }^{[13,14,15]}$. Pemecahan masalah melibatkan pencarian cara yang layak untuk mencapai tujuan ${ }^{[16]}$. Sedangkan menurut Gok kemampuan pemecahan masalah adalah kemampuan siswa menggunakan informasi yang ada untuk menentukan apa yang harus dikerjakan dalam suatu kedaan tertentu ${ }^{[15]}$. Menurut Chi dan Glaser, kemampuan pemecahan masalah merupakan aktivitas 
kognitif kompleks yang di dalamnya termasuk mendapatkan informasi dan mengorganisasikan dalam bentuk struktur pengetahuan ${ }^{[17]}$. Pada bidang fisika, pemecahan masalah fisika berkenaan dengan konsep fisika. Faktor yang mempengaruhi pemecahan masalah fisika adalah struktur pengetahuan yang dimiliki siswa yang memecahkan masalah dan karakter permasalahan ${ }^{[17]}$. Karakter permasalahan di antaranya ditunjukkan oleh format representasi soal yang disajikan ${ }^{[17,18]}$. Perbedaan antara siswa yang memiliki kemampuan rendah (novice) dan tinggi (expert) dalam pemecahan masalah fisika adalah bagaimana siswa mengorganisasi dan menggunakan pengetahuan, serta menghubungkan satu konsep dengan konsep yang lain ketika memecahkan masalah $^{[19,20,21,22,23]}$. Siswa yang memiliki kemampuan tinggi dalam pemecahan masalah fisika cenderung menggunakan argumen kualitatif berdasarkan konsep fisika yang mendasari masalah (deep feature), mengevaluasi solusi, dan cenderung menggunakan alat bantu representasi. Hal sebaliknya, siswa yang memiliki kemampuan rendah dalam pemecahan masalah fisika cenderung mengenali masalah bedasarkan sajian masalah (surface feature), tidak melakukan evaluasi, dan cenderung menggunakan rumus dalam memecahkan masalah ${ }^{[19,22,24]}$.

Indikator kemampuan pemecahan masalah pada penelitian ini diadaptasi dari Costa terdiri dari (1) menggunakan proses berpikir dasar untuk memecahkan kembali (resolve) masalah yang sudah diketahui atau yang sudah didefinisikan, (2) mengumpulkan fakta tentang masalah dan informasi yang diperlukan, (3) membuat interferensi atau memberikan penyelesaian alternatif dan menguji penyelesaian tersebut, (4) mereduksi penjelasan menjadi lebih sederhana dan mengeliminasi hal-hal yang tidak sesuai, (5) memberikan solusi ulang untuk membuat generalisasi ${ }^{[25]}$. Kemampuan pemecahan masalah diukur dengan menggunakan tes kemampuan pemecahan masalah berbentuk soal uraian.

\section{METODE PENELITIAN}

Rancangan penelitian ini bersifat mixed method. Metode penelitian yang digunakan pada penelitian ini adalah embedded research design dengan metode kualitatif lebih dominan daripada kuantitatif yang diadaptasi dari ${ }^{[26]}$. Rancangan penelitian ini ditampilkan pada Gambar 1.

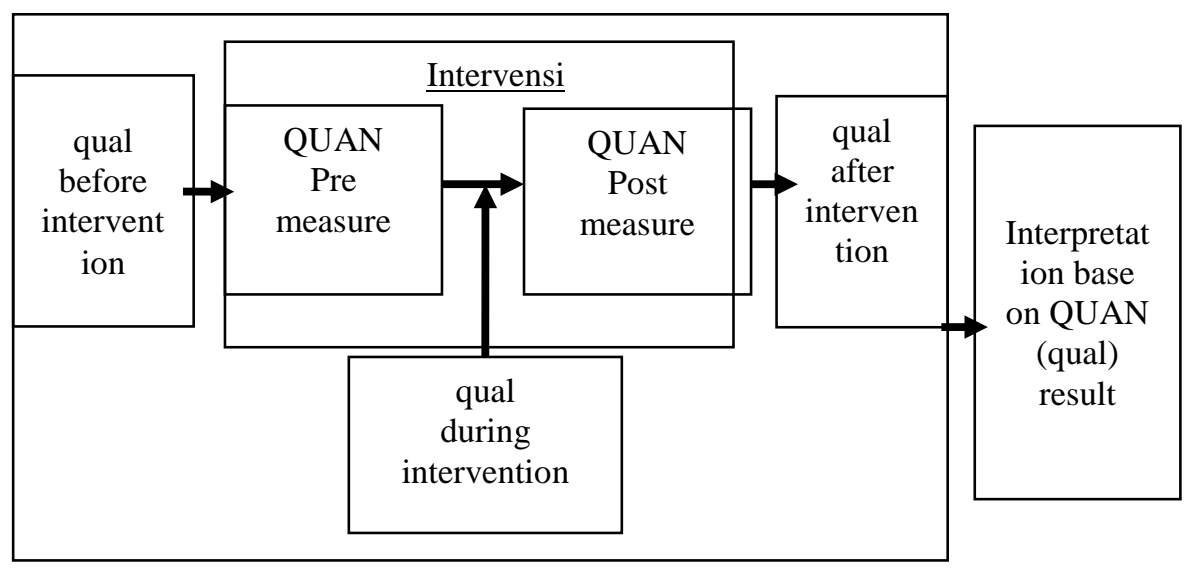

\section{Gambar 1. Embedded Researh Design}

Wawancara dan tes kemampuan pemecahan masalah untuk mengetahui pengelompokan kemampuan pemecahan masalah siswa rendah, sedang, dan tinggi, ketika intervensi diberikan untuk mengetahui kemampuan pemecahan masalah siswa, dan terakhir pembelajaran ketika intervensi diberikan yaitu berupa wawancara dengan siswa. Hasilnya digunakan untuk diinterpretasi dengan hasil penelitian kuantitatif.

Rancangan penelitian kuantitatif menggunakan pre-eksperimental design khusunya rancangan the one group pretest dan posttest design. Awal penelitian sebelum diberikan perlakuan, diberikan test pemecahan masalah sebagai data awal pretest siswa. Akhir penelitian setelah diberikan perlakuan, test pemecahan masalah kembali diberikan untuk mendapatkan data posttest siswa. Data pretest dan posttest

ini digunakan untuk menganalisis kemampuan pemecahan masalah siswa. Tes dan wawancara semiterstruktur mengenai pemecahan masalah digunakan sebagai alat pengumpulan data dalam metode penelitian campuran.

\section{HASIL DAN PEMBAHASAN}

Berdasarkan hasil analisis data kualitatif dan data kuantitatif didapatkan bahwa dari hasil wawancara dengan guru sebelum dilakukan perlakuan menunjukkan bahwa pembelajaran guru di kelas masih bersifat teacher centered, guru hanya menyampaikan materi pelajaran dengan metode 
ceramah, diskusi, dan tugas. Hal ini menyebabkan kemampuan pemecahan masalah siswa masih tergolong rendah. Hasil wawancara dengan siswa menunjukkan bahwa fisika merupakan suatu pelajaran yang sulit, siswa menganggap pelajaran fisika tidak menyenangkan yang menyebabkan hasil pretest siswa dalam pemecahan masalah masih tergolong rendah, hal ini senada dengan penelitian lain, Rusilowati menyatakan kesulitan belajar fisika yang dialami oleh siswa disebabkan oleh rendahnya penguasaan konsep, lemahnya kemampuan matematis, dan kurang mampunya siswa mengkonversi satuan ${ }^{[27]}$. Di samping itu, rendahnya kemampuan verbal juga menjadi faktor penyebab kesulitan belajar fisika siswa. Apabila model pembelajaran interactive demonstration diterapkan dalam pembelajaran maka dapat mempengaruhi kemampuan pemecahan masalah siswa yang berdampak pada prestasi belajar.

Dalam penelitian ini data kuantitaif diperoleh dari tes kemampuan pemecahan masalah sebelum dan sesudah perlakuan dilaksanakan. Awal penelitian sebelum diberikan perlakuan, diberikan tes pemecahan masalah sebagai data awal pretest siswa. Akhir penelitian setelah diberikan perlakuan, test pemecahan masalah kembali diberikan untuk mendapatkan data posttest siswa. Data pretest dan posttest ini digunakan untuk menganalisis kemampuan pemecahan masalah siswa. Data kemampuan pemecahan masalah siswa diperoleh dari 20 soal uraian. Soal test kemampuan pemecahan masalah telah divalidasi oleh dua dosen ahli, selain validasi isi soal juga harus di uji coba terlebih dahulu. Soal tes kemampuan pemecahan masalah dirancang oleh peneliti pada saat validasi isi dan uji coba berjumlah 26 soal yang disesuaikan dengan indikator pembelajaran materi kalor. Setelah uji coba soal, soal harus di analisis dengan uji taraf kesukaran, uji daya beda, uji validitas, dan uji reliabilitas. Setelah dilakukan uji prasyarat, dilanjutkan dengan uji hipotesis.

Hasil pretest dan posttest kemampuan pemecahan masalah siswa di hitung dengan melihat perbandingan nilai antara nilai sebelum dilakukannya perlakuan dengan nilai sesudah dilakukannya perlakuan dengan uji t-test berpasangan. Tugas $t$-test adalah menguji perbedaan rerata antara dua sampel. T-test yang digunakan dalam analisis data penelitian ini adalah $t$-test berpasangan. $\mathrm{T}$-test digunakan sebagai indicator ada tidaknya pengaruh yang disebabkan perlakuan yang dilakukan.

Tabel 2. Ringkasan Hasil Rata-Rata Kemampuan Pemecahan Masalah Siswa

Sebelum Sesudah
Perlakuan Perlakuan hitung Sig Ket

\begin{tabular}{lcccc}
\hline Jumlah Siswa & 34 & 34 & & \\
Kemampuan & 33,1765 & 66,9706 & 29,549 & 0,000 Berbe \\
$\begin{array}{l}\text { Pemecahan } \\
\text { Masalah }\end{array}$ & & & & da \\
\hline
\end{tabular}

$\mathrm{t}_{\text {tabel }}=\mathrm{t}_{(34,5 \%)}=2,032$

Pada Tabel 2, kemampuan pemecahan masalah t-hitung sebesar 29,549 dengan nilai signifikansi 0,000. Hal ini menunjukkan bahwa terdapat perbedaan nyata sebelum dan sesudah perlakuan $\left(\mathrm{H}_{0}\right.$ ditolak) karena t hitung $(29,549)$ lebih besar dari t tabel $(2,032)$ atau nilai signifikansi $(0,000)$ lebih kecil dari $\alpha=5 \% \quad(0,05)$. Rata-rata skor pretest adalah 33,1765 dan rata-rata skor posttest adalah 66,9706. Hal ini menunjukkan bahwa terdapat peningkatan kemampuan pemecahan masalah siswa.

Hal ini senada dengan penelitian yang dilakukan oleh Stice, mengatakan adanya peningkatan kemampuan pemecahan masalah siswa jika dibandingkan dengan pembelajaran konvensional ${ }^{[28]}$. Proses pembelajaran yang dilakukan dikelas konvensional adalah pembelajaran yangs erring dilakukan dalam keseharian, yaitu: ceramah, diskusi, dan presentasi hasil diskusi. Penelitian menggunakan interactive demonstration ini telah diterapkan oleh Muyassaroh, yang menyatakan bahwa kemampuan pemecahan masalah siswa dengan pembelajaran level of inquiry-interactive demonstration lebih tinggi daripada level of inquiry-discovery learning, hal ini tercermin pada langkah-langkah pembelajaran yang dapat memfasilitasi peserta didik menjelaskan dan membuat prediksi yang memungkinkan guru mengidentifikasi dan menyelesaikan konsepsi siswa $^{[29]}$. Pembelajaran dengan interactive demonstration dapat membuat prestasi belajar siswa lebih tinggi daripada siswa yang belajar secara konvensional karena selain melakukan percobaan pada tahap manipulation siswa juga diberikan permasalahan-permasalahan pada tahap application yang dapat melatih siswa dalam berpikir, serta menghubungkan materi pembelajaran dengan konteks kehidupan sehari-hari. Pembelajaran interactive demonstration melibatkan siswa dalam mengkonstruksi pengetahuan dari pengalaman langsung ketika percobaan, hal ini senada dengan penelitian Santyasa, bahwa keterlibatan langsung siswa dalam proses pembelajaran dapat meningkatkan hasil belajar dan dapat meningkatkan keterampilan berpikir dalam memecahkan $\operatorname{masalah}^{[30]}$.

Penelitian yang dilakukan menghasilkan temuantemuan memperkuat hasil uji statistik bahwa kemampuan pemecahan masalah fisika siswa sebelum dan sesudah perlakuan dikelas dengan pembelajaran interactive demonstration mengalami 
peningkatan. Pada saat posttest siswa terlihat lebih siap dan siswa lebih paham materi yang diujikan.

\section{KESIMPULAN}

Berdasarkan hasil penelitian dan hasil uji hipotesis yang telah dilakukan, maka dapat disimpulkan sebagai berikut.

1. Pembelajaran interactive demonstration berpengaruh terhadap kemampuan pemecahan masalah siswa.

2. Pengaruh strategi pembelajaran interactive demonstration berdasarkan hasil penelitian dan analisis data menunjukkan bahwa tingkat kemampuan pemecahan masalah siswa mengalami peningkatan.

3. Pembelajaran interactive demonstration dapat diajarkan pada semua materi dalam pembelajaran fisika, sehingga pembelajaran fisika dapat lebih aktif dan bervariatif.

4. Guru sebagai tenaga pendidik harus memberikan kenyamanan dalam pembelajaran di kelas, salah satunya adalah membangun interaksi yang positif dalam kelas. interactive demonstration dapat memberikan nuansa belajar yang lebih interaktif antara siswa dengan guru maupun antar siswa. Kegiatan pembelajaran yang teacher centered di kelas akan cepat membuat siswa bosan dan jenuh, sehingga keinginan siswa untuk belajar akan berkurang yang berakibat pada rendahnya prestasi belajar siswa tersebut. Oleh karena itu, pembelajaran perlu dirancang dengan pemberian masalah-masalah yang dapat membuat siswa aktif dan kreatif, sehingga siswa terbiasa untuk menyelesaikan suatu permasalahan dan siswa diharuskan mengeluarkan kemampuannya dalam pemecahan masalah kepada teman-temannya di kelas, sehingga terjadi interaksi yang positif pada saat pembelajaran.

\section{UCAPAN TERIMA KASIH}

Ucapan terima kasih penulis sampaikan kepada lembaga yang telah memberikan kontribusi pada data penelitian, yaitu SMA Negeri 1 Bangil.

\section{REFERENSI}

[1] National Research Council. 1996. National Science Education Standard. Washington DC: National Academy Press.

[2] Mims, Clif. 2003. Authentic Learning: A Practical Introduction \& Guide for Implementation. A Middle School Computer Technologies Journal, vol 6, Issue 1, Winter 2003, ISSN 10979778.

${ }^{[3]}$ Hoellwarth, C., Moelter, M. J., \& Knight, R. D. A. 2005. Direct Comparison of Conceptual Learning and Problem Solving Ability in Traditional and Studio Style Classrooms. American Journal of Physics, vol. 73, 459.

[4] Walsh.L, N. Howard R.G, and Bowe. B., 2007. Phenomenography Study of Students' Problem Solving Approach in Physics. Physics Education Research, vol. 1, 12.

[5] Brad. A., 2011. A Study of The Problem Solving Activity in High School Student: Strategies and Self-Regulated Learning. Acta Didactica Napocensia, vol. 21, 30.

[6] Ogunleye. A. O., 2009. Teacher and Student Perception of Student Problem Solving Difficulties in Physics: Implication for Remidion. Journal of College Teaching \& Learning, vol. 85, 90.

[7] Ikhwanuddin, Jaedun. A. and Purwantoro, 2010. D, Problem Solving dalam Pembelajaran Fisika untuk Meningkatkan Kemampuan Mahasiswa Berpikir Analitis. Jurnal Kependidikan. vol. 14, 16.

[8] Wilhelm. J, Thacker. B, and Wilhelm. R. Creating Constructivist Physics for Introductory University Classes. Electronic Journal of Science Education, 2007.

[9] Wenning, Carl. J. 2012. Levels of Inquiry: Using Inquiry Spectrum Learning Sequences to Teach Science. J. Phys. Tchr. Educ. Online, 5(3).

${ }^{[10]}$ Violeta, S dan Loreta, R., 2010, "The Learning Physics Impact of Interactive Lecture Demonstration", Problems of Education in the 21th Century, 24, 120-129.

${ }^{[11]}$ Wenning, Carl J. 2011. The Levels of Inquiry Model of Science Teaching. J. Phys. Tchr. Educ. Online, 6(2).

${ }^{[12]}$ Wenning, Carl. J. 2010. Levels of Inquiry Model of Science Teaching: Learning sequences to lesson plans. J. Phys. Tchr. Educ. Online, 5(3).

${ }^{[13]}$ Selcuk. G. S, Caliskan. S, Erol. M, The Effect of Problem Solving Instruction on Physics Achievement, Problem Solving Performance and Strategy Use. Latin America Journal Physics Education. (Online). 2(3) 2008, pp151- 166.

${ }^{[14]}$ Gok. T, Silay. I, Effect of Problem Solving Strategy Teaching on the Problem Solving Attitude of Cooperating Learning Group in Physics Education. Journal of Theory and Practice in Education, 2008.

${ }^{[15]}$ Gok. T, Silay. I, The Effects of Problem Solving Strategies on Students' Achievement, Attitude and 
Motivation. LatinAmerican Journal of Physics Education, 4(1) 2010, pp 7-21.

${ }^{[16]}$ Santrock, J.W. 2011. Educational Psychology. New York: McGraw-Hill.

${ }^{[17]}$ Chi, M. T. H., \& Glaser, R. (1985). Problemsolving ability. Dalam R. J. Sternberg (Ed.), Human abilities: An information-processing approach (227-250). New York: Freeman.

${ }^{[18]}$ De Cock, M. 2012. Representation Use and Strategy Choice in Physics Problem Solving. Physical Review Special Topics - Physics Education Research.

${ }^{[19]}$ Chi, M.T.H., Feltovich, P. J., \& Glaser, R. 1981. Categorization and representation of physics problems by experts and novices. 5:121-152.

${ }^{[20]}$ Singh, C. 2008a. Assessing Student Expertise in Introductory Physics with Isomorphic Problems. I. Performance on Nonintuitive Problem Pair From Introductory. Physical Review Special Topics Physics Education Research.

${ }^{[21]}$ Singh, C. 2008b. Assessing Student Expertise in Introductory Physics with Isomorphic Problems. II. Effect of Some Potential Factors on Problem Solving and Transfer. Physical Review Special Topics - Physics Education Research.

${ }^{[22]}$ Mason, A. \& Singh, C. 2011. Assessing Expertise in Introductory Physics Using Categorization Task. Physical Review Special Topics - Physics Education Research.

${ }^{[23]}$ Shih, Y.L. \& Singh, C. 2013. Using an isomorphic problem pair to learn introductory physics: Transferring from a two-step problem to a three-step problem. Physical Review Special Topics - Physics Education Research.

${ }^{[24]}$ Savelsbergh, E. R., de Jong, T., \& FergusonHessler, M.G.M. 2011. Choosing The Right Solution Approach: The Crucial Role Of Situational Knowledge in Electricity and
Magnetism. Physical Review Special Topics Physics Education Research

${ }^{[25]}$ Costa, A.L.1985. Developing Minds. Alexandria, Virginia : ASCD

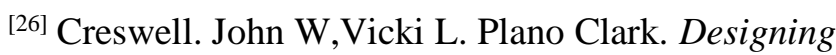
and conducting Mixed Methods Research. London: Sage Publications. 2008.

${ }^{[27]}$ Rusilowati. A, Profil Kesulitan Belajar Fisik Bahasan Kelistrikan Siswa SMA di Kota Semarang. Jurnal Pendidikan Fisika Indonesia. Vol. 4 No. 2, 2006.

${ }^{[28]}$ Stice. J.E. Teaching Problem Solving [Online]. 1987.Tersedia:http://wwwcsi.unian.it/educa/proble msolving/stice_ps.html

${ }^{[29]}$ Muyassaroh, Indana Zulfa. 2015. Pengaruh Level of Inquiry terhadap Kemampuan Pemecahan Masalah Fisika Pesrta Didik Kelas X SMA. Skripsi tidak diterbitkan. Malang: Program Studi Pendidikan Fisika Universitas Negeri Malang.

${ }^{[30]}$ Santyasa. (2007). Pengembangan Pemahaman Konsep Dan Kemampuan Pemecahan Masalah Fisika Bagi Siswa SMA Dengan Pemberdayaan Model Perubahan Konseptual Berseting Investigasi Kelompok. Jurnal Pendidikan Fisika Universitas Pendidikan Ganesha.

\section{Biografi Penulis}

Rismatul Azizah, lahir di Bangil, Pasuruan, pada tanggal 07 November 1989. Pada tahun 2011 telah menyelesaikan Sarjana Pendidikan dari Program Studi Pendidikan Fisika, Fakultas Matematika dan Ilmu Pengetahuan Alam, Universitas Negeri Malang. Saat ini sedang menempuh Pascasarjana pada Program Studi Pendidikan Fisika di Universitas Negeri Malang. Penelitian untuk tesis yang sedang dilakukan saat ini berkaitan dengan pola berpikir dan penguasaan konsep fisika melalui interactive demonstration pada siswa SMA kelas X. 